\title{
SLOPE FAILURES IN THE FAROE - SHETLAND CHANNEL
}

\author{
D. LONG, A. G. STEVENSON, C. K. WILSON, J. BULAT
}

British Geological Survey, West Mains Road, Edinburgh EH9 3LA, UK

\begin{abstract}
Submarine slides varying from $0.002 \mathrm{~km}^{3}$ to more than $360 \mathrm{~km}^{3}$ have been identified in the Faroe - Shetland Channel using a wide range of surveys. Although not a major constraint to seabed use slides need to be considered as a potential geohazard. Dynamic loading of contouritic horizons is considered the triggering mechanism of these thin layer failures.
\end{abstract}

Keywords: Faroe - Shetland Channel, submarine slide, contourites, seismicity

\section{Introduction and regional setting}

The slope of the Faroe - Shetland Channel (FSC) like that of other glaciated margins around the world shows evidence of downslope movement associated with the mode of deposition e.g. debris flows but it also shows limited evidence for submarine slides (Figure 1). Although some margins such as offshore mid-Norway display numerous slides they are sites of rapid deposition often with $>0.5 \mathrm{~km}$ of Quaternary deposits. With the exception of the North Sea Fan the west Shetland slope typically has less than 200 $\mathrm{m}$ of deposits. At the southern end of the Faroe - Shetland Channel debris flows interpreted as deposited by ice sheets extending beyond the shelf break extend down the slope to the floor of the FSC. North of about $61^{\circ} \mathrm{N}$ debris flows terminate about half way down the slope with occasional turbidite flows.

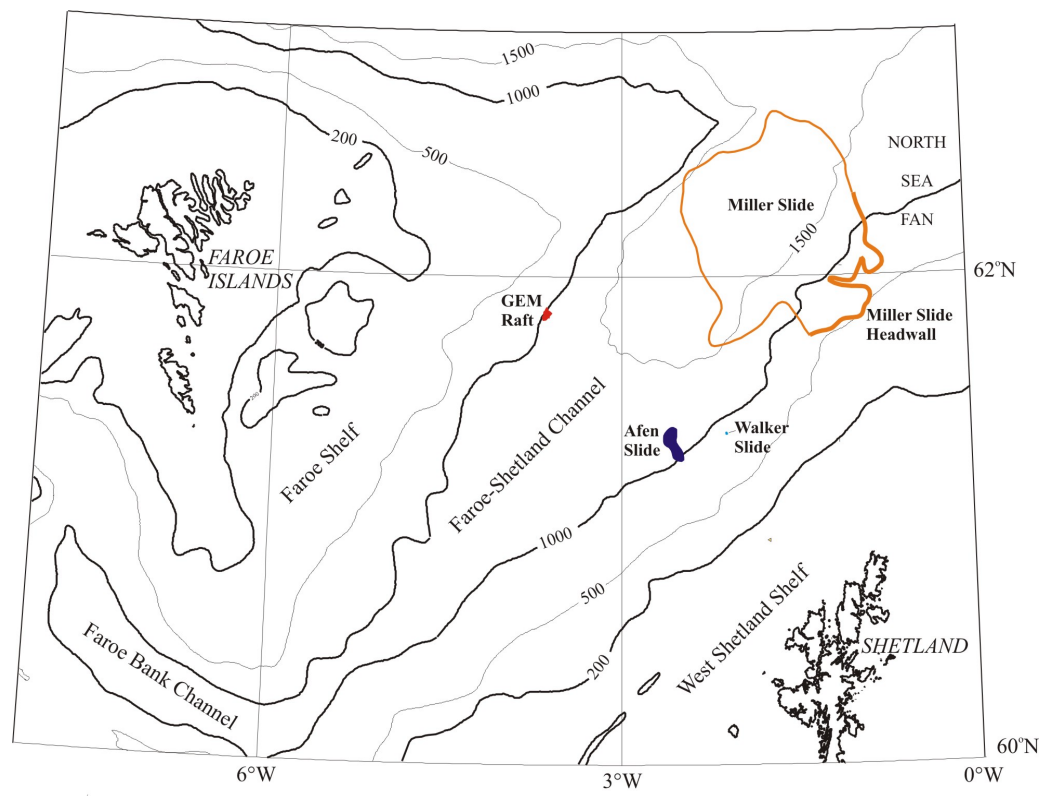

Figure 1. Location of submarine slides in the Faroe -Shetland Channel 
Further north debris flows are even more restricted in water depth except on the North Sea Fan. Along-slope currents and the deposition of contourite deposits predominate northwards. One major slide has been identified so far, the Miller Slide on the western edge of the North Sea Fan (Figure 1). However high resolution imaging of the seafloor has located three seabed slides suggesting sliding is an integral part of slope development.

\section{Data}

Regional shallow seismic (airgun, sparker and boomer) was collected with a line spacing of 7 to $10 \mathrm{~km}$ along the West Shetland shelf and slope in the 1970's and early 1980 's as part of the British Geological Survey's regional mapping programme south of $62^{\circ} \mathrm{N}$. This resulted in the subsequent publication of several 1:250,000 scale maps and regional memoir (Stoker et al., 1993). Following expansion of oil company interest in the margin west of Shetland in the early 1990's additional data became available. These included small area site surveys and first return data from 3D exploration seismic. Following interpretation of these data for the Western Frontiers Association, a joint industry programme (Long et al., 1998) an additional high resolution survey was undertaken on a seabed slide in 2000 (Haflidison et al., 2000) as part of the EU funded COSTA programme. Airgun and sparker surveys were conducted north of $62^{\circ} \mathrm{N}$ to extend the regional mapping programme of the 1980's.

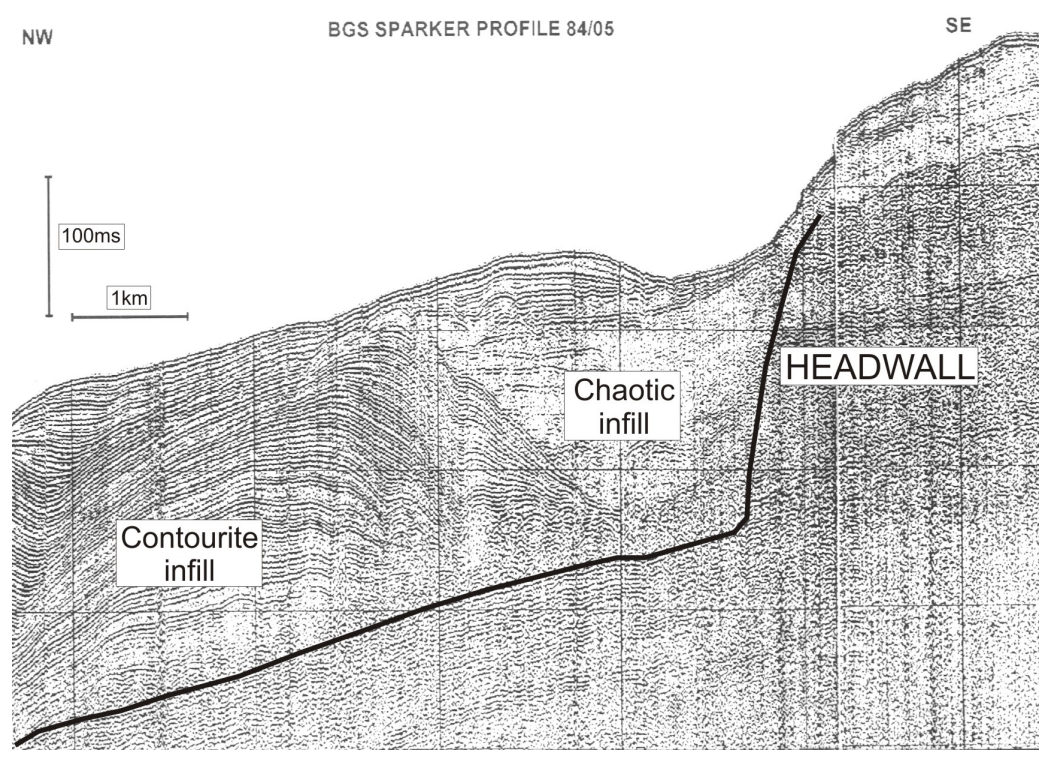

Figure 2. Sparker record of the Miller Slide headwall and infill 


\section{Submarine Slides}

\subsection{MILLER SLIDE}

At the northern end of the FSC on the southern limit of the North Sea Fan regional surveys identify a large slide named the Miller Slide (Long and Bone 1988). It has only a minor surface expression due to the near complete infill, recent data indicates that it is at least $35 \mathrm{~km}$ wide, with a headwall height locally exceeding $180 \mathrm{~m}$ (Figure 2) and debris flow runouts extending to more than $50 \mathrm{~km}$. The volume of transported material exceeds $360 \mathrm{~km}^{3}$ (Figure 3).

The age of the slide has recently been reassessed in light of the reinterpretation of the sediments which it truncates. Difficulties in extrapolating the seismic stratigraphy from the North Sea across the West Shetland Shelf meant that the sequences mapped on the West Shetland Slope in the Miller area by Stevenson (1991) were tentative due to the thick off-lapping sequence of sediments both pre-dating and post-dating the main Quaternary unconformity in the region. New data suggest that sediments equivalent to the Middle to Upper Pleistocene Mariner Formation are included in the sediments cut by the Miller Slide.

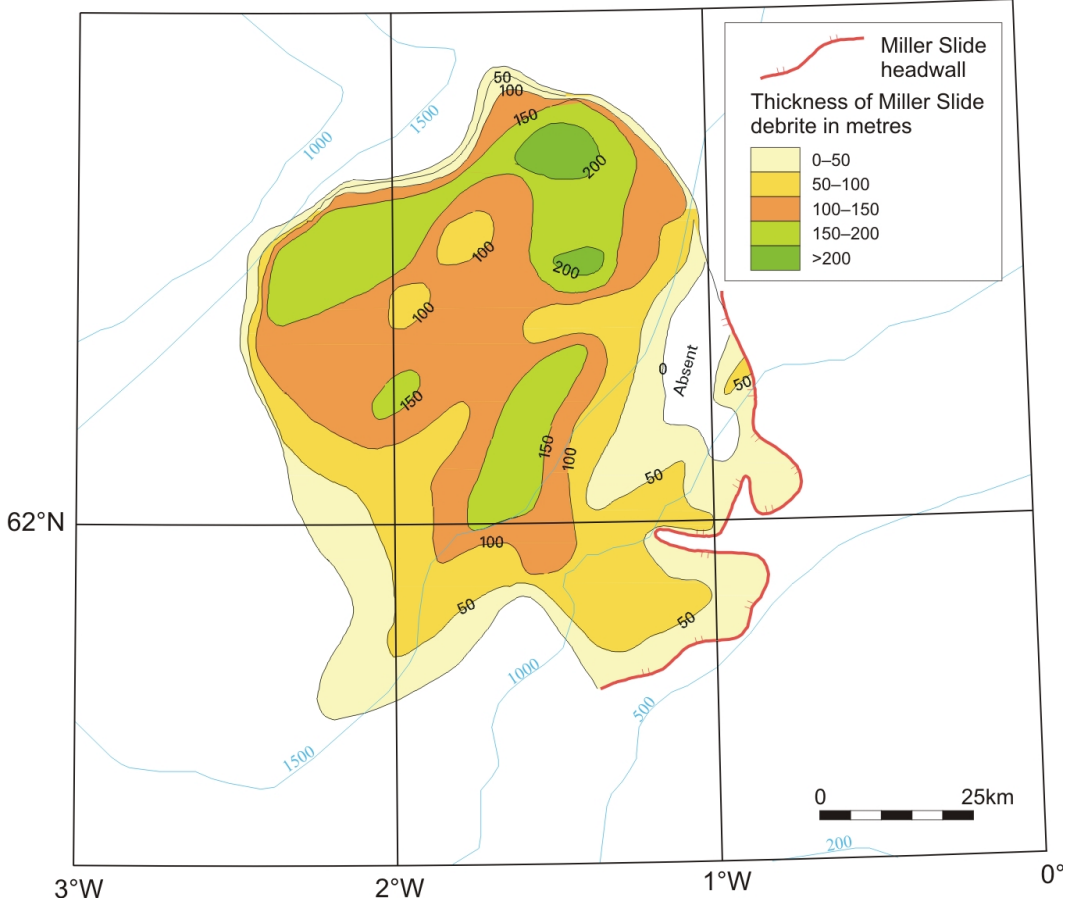

Figure 3. Location of the Miller Slide headwall and debris flow deposits.

Furthermore, the slide is post-dated by a thick series of contourites that can be traced north-eastward and correlated with a sequence of hemipelagic sediments which occur across the North Sea Fan area. The age of these hemipelagic sediments is not known but 
their stratigraphic position suggests that they may have been deposited during an interglacial within the Saalian glacial period. It is proposed that this may have been the Grødeland Interglacial which Sejrup et al (1999) correlate with Oxygen Isotope Stage 7 and give an age of about 200,000 kyr.
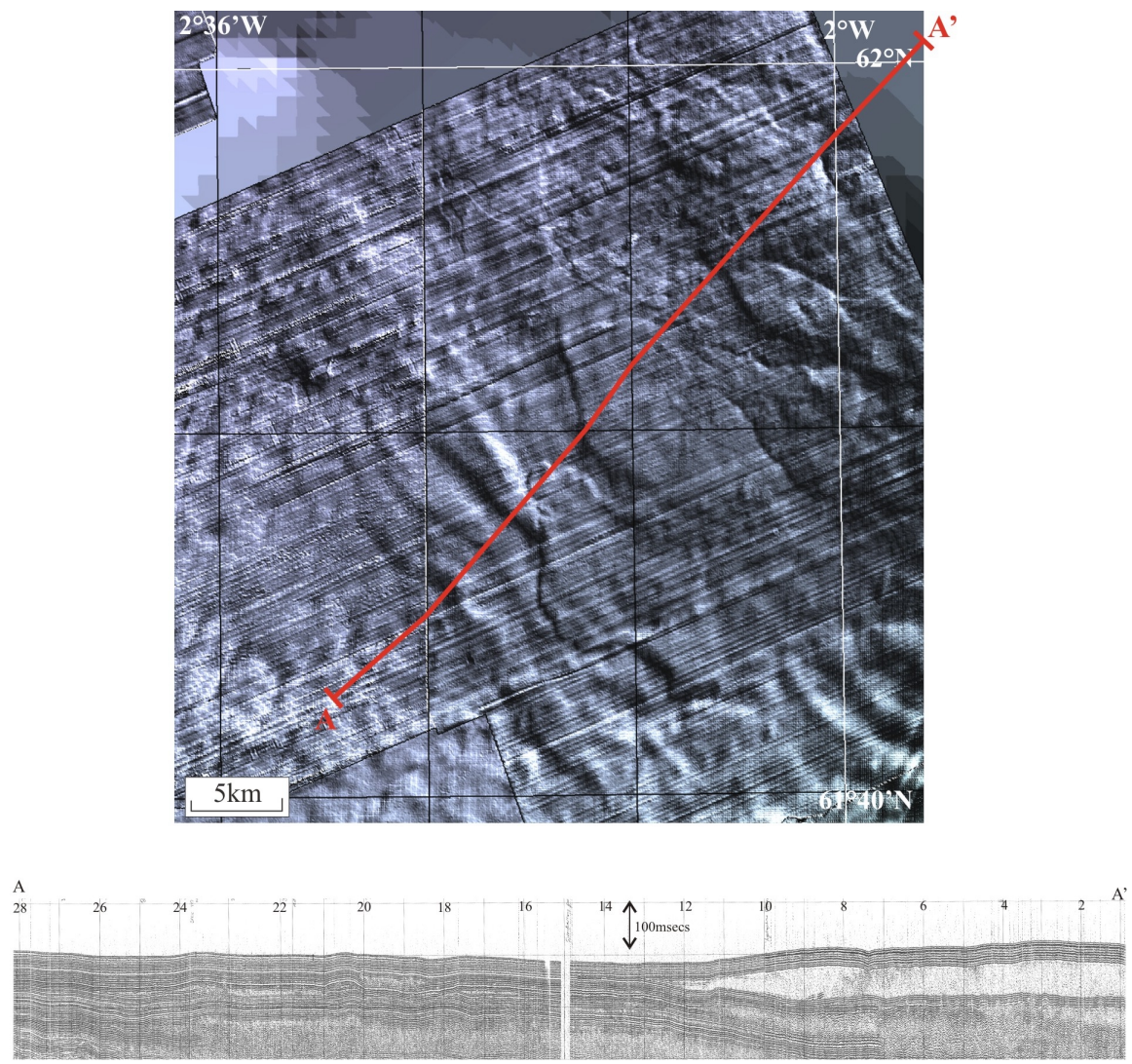

BGS sparker profile $84 / 05-32$

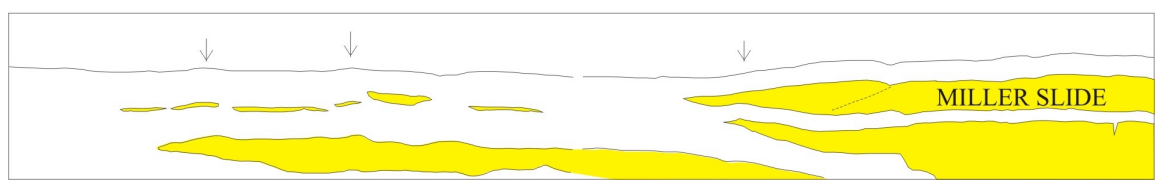

Figure 4. Seabed image at the northern end of the Faroe - Shetland Channel showing seabed undulations reflecting buried debris flows upto $200 \mathrm{~ms}$ below seabed. The large buried debris flow on the right belongs to the Miller Slide.

Based on evidence of the North Sea Fan in the Norwegian sector other submarine slides may occur north of $62^{\circ} \mathrm{N}$. Only limited studies have been done so far (Evans et al 2002). The seabed image created from the first return of 3D seismics reveals slight topographic highs on the floor of the FSC north of about $61^{\circ} 45^{\prime} \mathrm{N}$ that represent sediment drapes 
over buried debris flows (Figure 4) (Bulat and Long, 2001). There is insufficient 2D shallow seismic data to identify the source of these debris flows it is considered that most originate on the southern flank of the North Sea Fan but a Faroese slope failure cannot be ruled out.

\subsection{THE AFEN SLIDE}

This distinct seabed slide was first identified on sonar data (Masson, 2001, UKOOA, 2000). It has subsequently been imaged from first returns of 3D data (Long et al., 1998, Bulat this volume, Wilson et al., this volume). The 3D data show that the slide as determined by its topographic expression is greater than that initially observed on the sonar data. It is $12 \mathrm{~km} \mathrm{x} 4 \mathrm{~km}$ in size. The thickness of displaced sediments is 10 to 20 $\mathrm{m}$ involving the transport of about $0.4 \mathrm{~km}^{3}$ of sediments. This multistage Holocene slide involved failure along reflectors interpreted as being contouritic horizons. For a complete evaluation of this slide see Wilson et al., (this volume).

\subsection{PALAEO-AFEN SLIDE}

The high resolution deep towed boomer profiles collected across the Afen Slide have revealed the presence of a similar size slide buried about $50 \mathrm{~ms}$ below the seabed slide (Figure 5). This slide has its headwall in the same water depth. The maximum width is slightly smaller at $2.5 \mathrm{~km}$ but the run out is comparable (Figure 6). The thickness of removed sediments is about $20 \mathrm{~m}$. The repeated failure at this location suggests that its location may be significant. These failures are located above the Victory Lineament with headwalls where contourite sediments occur.

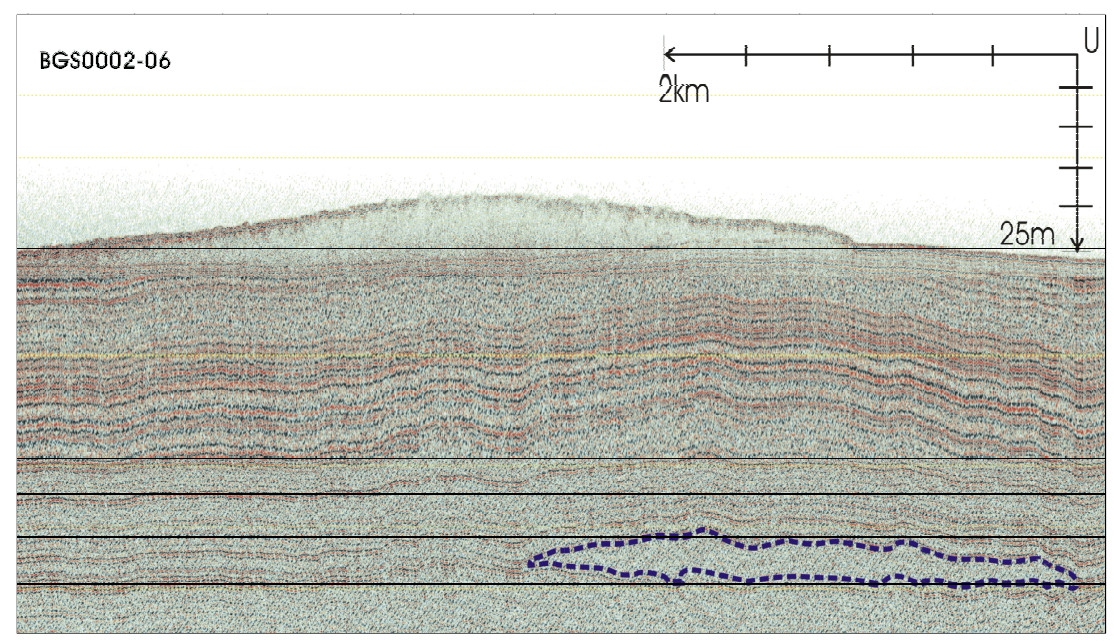

Figure 5. Buried debris flow located beneath the debris flow of the Afen Slide. 


\subsection{WALKER SLIDE}

The Walker Slide has only recently been identified at $61^{\circ} 21^{\prime} \mathrm{N} 2^{\circ} 06^{\prime} \mathrm{W}$ (Figure 1) on a seabed image derived from 3D exploration. The first images were created using a $100 \mathrm{~m}$ grid, however following a regridding at $25 \mathrm{~m}$ (Bulat this volume) a landslide of less than $1 \mathrm{~km}$ width and about $1.5 \mathrm{~km}$ length can be seen (Figure 7). No shallow seismic profile data is known across this feature to confirm interpretation. Individual seabed picks indicate that the slide is very shallow, about $4 \mathrm{~m}$ giving a volume of $0.002 \mathrm{~km}^{3}$ for the transported sediment. It is located in $850 \mathrm{~m}$ water depth, a similar level to that of the Afen Slide where contourite sediments are thickest. Therefore a similar slide mechanism of sliding on weak contouritic horizons, as favoured for the Afen Slide (Wilson et al, this volume) is considered most likely. This feature is only faintly recognizable on deep towed sidescan images suggesting that there have has been little change in the seabed sediments' acoustic properties.

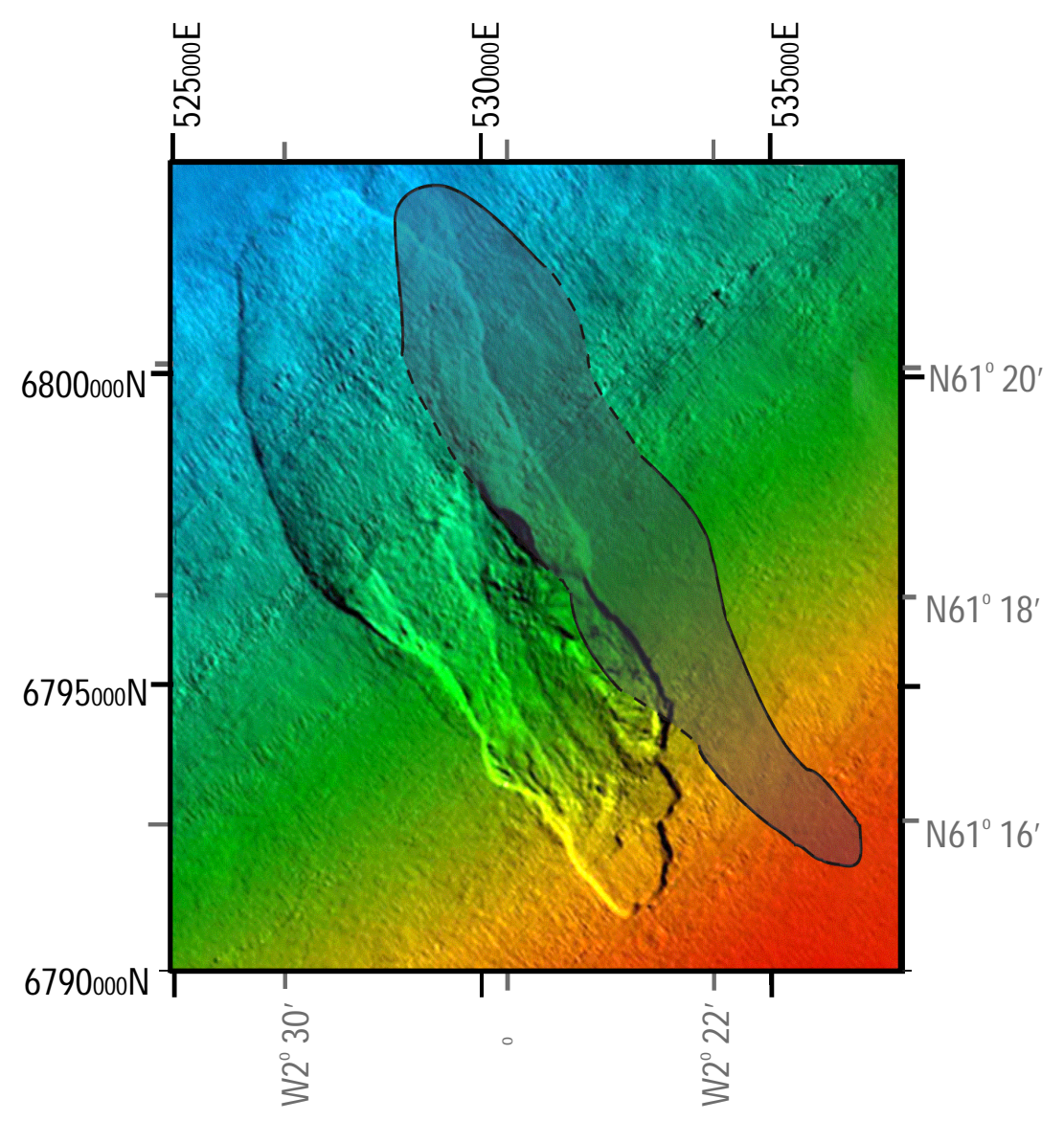

Figure 6. The outline of the Palaeo-Afen Slide mimics that of the Afen Slide on the seabed. 
However it is located towards the edge of a swath making recognition uncertain. Its subdubed appearance on the 3D seabed image compared with the Afen Slide (Figure 7) may indicate that the feature is older than the mid-Holocene age ascribed for the latter.

\subsection{GEM RAFT}

Regional studies of the Faroese slope of the FSC have been conducted on behalf of an industry consortium (www.foib.fo). Studies have integrated 2D and 3D seismics with deep towed sidescan sonar data. These have revealed a small slide termed the Gem Raft. It is located at $61^{\circ} 50^{\prime} \mathrm{N} 3^{\circ} 40^{\prime} \mathrm{W}$ (Figure 1) and covers an area of about $7 \times 3 \mathrm{~km}$. The sidescan sonar images suggest a simple slab that has moved a sort distance $(<1 \mathrm{~km})$ downslope with some rotation. Like the Afen Slide it occurs above the Victory Lineament and therefore may have experienced the same triggering mechanism.

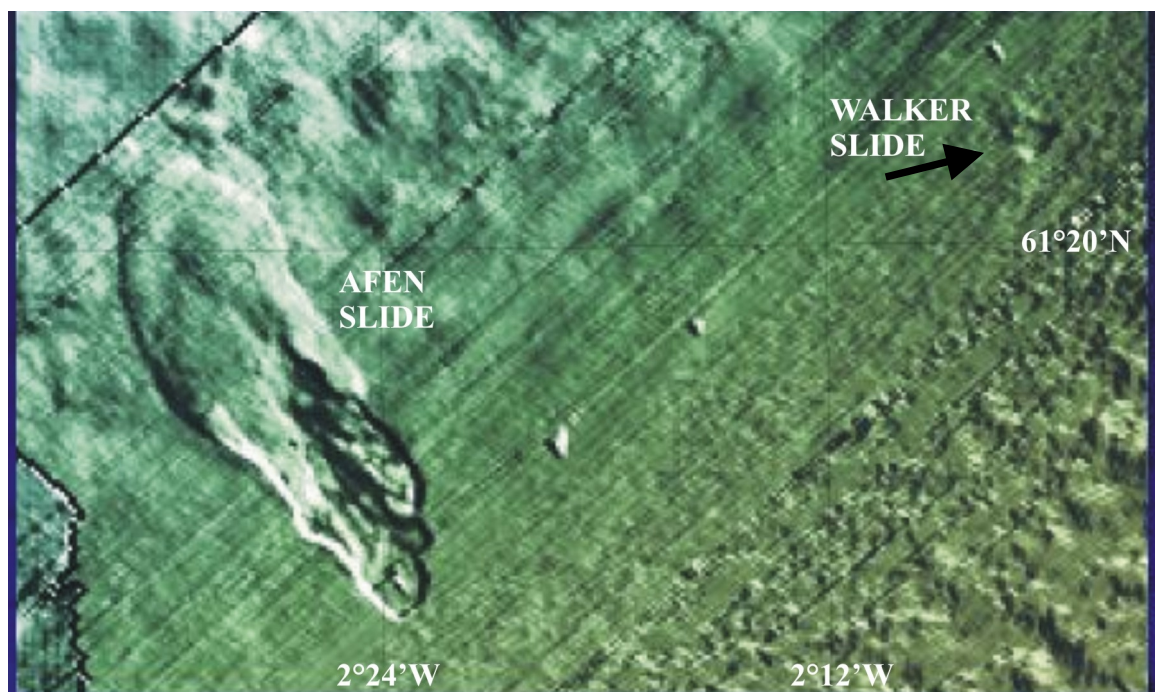

Figure 7. Showing the Afen and Walker slides.

\section{Conclusions}

The submarine slides identified in the Faroe - Shetland Channel vary considerably in size from $0.002 \mathrm{~km}^{3}$ to more than $360 \mathrm{~km}^{3}$ but all have contouritic sediments associated with them. Such along slope sediments which become dominant in deglaciation and interglacial periods, are commonly more porous than the intervening glacial deposits. They are considered to have lower strengths, in particular lower remoulded strength. They are also susceptible to liquefaction under dynamic loading, creating not only a plane of weakness but also the potential of increased pore pressure in the surrounding cohesive sediments. Failures away from the North Sea Fan are the result of movement of relatively thin layers but those within the fan sediments are larger and may involve 
retrogressive failure as noted on slides to the northeast on the Norwegian margin (Bryn et al 2002).

The slides identified so far are located in close proximity to deep structural controls. Basinal studies have revealed several NW-SE trending lineaments that have influenced sedimentation patterns. These features developed during the opening of the North Atlantic. These lineaments at the northern end of the FSC are the sites of geological processes active within the last 10 million years including transpressional folding and diapiric activity and may still be active today (Ritchie et al., in prep). Active seismic monitoring over the last five years with detection capabilities of magnitude 2 has shown the FSC to be a low activity area (Ford et al 2002). There has been only negligible historical seismicity (Musson 1998).

\section{Acknowledgments}

Thanks to the members of the Western Frontiers Association and the EU funded COSTA program (EVK3-CT-1999-00006) for funding various studies into instability of the Faroe-Shetland Channel. The reviewers are thanked for their helpful comments. Published with permission from the Director General of the British Geological Survey.

\section{References}

Bryn, P and 5 others. 2002. The Storegga geomodel and its use in slide risk evaluation. International Conference on Offshore Site Investigation and Geotechnics - sustainability through diversity. 26-28 November 2002 London, Society for Underwater Technology.

Bulat 2003. Imaging the Afen Slide from commercial 3D seismic-methodology and comparisons with highresolution data. In: Submarine mass movements and their consequences. J.Locat and J Mienert Ed., Advances in Natural and Technological Hazards Research Series, KLUWER, (this volume).

Bulat, J. and Long, D. 2001 Images of the seabed in the Faroe-Shetland Channel from commercial 3D seismic data. Marine Geophysical Researches, 22: 345-367

Evans, D., McGiveron, S., Harrison, Z., Bryn, P. and Berg, K., 2002. Along-slope variation in the late Neogene evolution of the mid-Norwegian margin in response to uplift and tectonism. In; Dore, A.G., Cartwright, J.A., Stoker, M.S., Turner, J.P. and White, N. 2002. Exhumation of the North Atlantic Margin: Timing, Mechanisms and Implications for Petroleum Exploration. Geological Society, London, Special Publications, 196, 139-151.

Ford, G., Simpson, B. and Ottemoller, L. 2002. NW Scotland offshore seismicity: sixth annual report to 30 September 2002. British Geological Survey Technical Report CR/02/285.

Haflidison, $\mathrm{H}$ and 7 others, 2000. Marine geophysical cruise report on the Shetland margin: Afen Slide. Dept of Geology, University of Bergen, Norway

Long, D. and Bone, B.D. 1990. Sediment instability on the continental slope of northwestern Europe. Proceedings of Oceanology International 90, volume 2.

Long, D., and 3 others. 1998. The Western Frontiers Association - an example of joint industry funded regional studies of the shallow geology in a frontier area. In: Ardus, D.A. and 5 others (eds) Proceedings of the Offshore Site Investigation and Foundation Behaviour - "new frontiers" Conference 22-24 September 1998, Society for Underwater Technology.

Masson, D.G., 2001. Sedimentary processes shaping the eastern slope of the Faeroe-Shetland Channel. Continental Shelf Research 21: 825-857.

Musson, R.M.W. 1998. Historical Seismicity of the Western Frontiers Area British Geological Survey Technical Report WL/98/26C 
Ritchie, J.D., Johnson, $\mathrm{H}$ and Kimbell, G.S. The nature, age and origin of Cenozoic compressional deformation within the north Faroe-Shetland Basin (in prep)

Sejrup, H.P., and 4 others 1999. A stage 7 marine interglacial record (the Grodeland Interglacial) on Jaeren, southwestern Norway; foraminiferal, stable isotopes and amino acid evidence Boreas, 28: 326-346

Stevenson, A.G. 1991. Miller 1:250 000 Sheet. Quaternary Geology. British Geological Survey, London.

Stoker, M.S., Hitchen, K. and Graham, C.G. 1993 The geology of the Hebrides and West Shetland shelves, and adjacent deep-water areas. British Geological Survey United Kingdom Offshore Regional Report. (London, HMSO)

UKOOA, 2000. Atlantic margin environmental surveys of the seafloor $1996 \& 1998$. CD-Rom issued by the United Kingdom Offshore Operators Association (UKOOA) ISBN 0-9538399-0-7

Wilson, C.K., Long, D. and Bulat, J. 2003. The Afen Slide - a multistage slope failure in the Faroe - Shetland Channel . In: Submarine mass movements and their consequences. J.Locat and J Mienert Ed., Advances in Natural and Technological Hazards Research Series, KLUWER, (this volume). 